\title{
Massais, mulatas, meretrizes: imagens da sexualidade feminina no Rio de Janeiro dos anos $1920^{*}$
}

\author{
Tiago de Melo Gomes**
}

\section{Resumo}

A década de 1920 foi marcada por ansiedades masculinas: homens de elite e classe média pareciam extremamente preocupados com a "invasão" do espaço público por mulheres. Este artigo estuda a resposta dada por estes homens ao fenômeno, com ênfase especial à extrema sexualização atribuída por estes contemporâneos às jovens mulheres e às comparações feitas entre seus comportamentos e o de prostitutas, afrobrasileiras e "selvagens".

Palavras-chave: Gênero, Raça, Sexualidade, Modernidade.

\footnotetext{
* Recebido para publicação em fevereiro de 2003, aceito em novembro de 2003.

*** Professor do Centro Universitário do Leste - Unileste, Coronel Fabriciano-MG, Brasil.chs@unilestemg.br
} 
Massais, mulatas, meretrizes

Maassai, Mulatas and Hookers:

Images of Female Sexuality in 1920's Rio de Janeiro

\begin{abstract}
The 1920s were characterized in the cultural context by male anxieties: elite and middle-class men seemed to be seriously concerned about an "invasion" of the public space by women. This article studies the response of these men to the phenomena, emphasizing especially the extreme sexualization attributed by these contemporaries to young women and the comparisons made of their behaviors and the behavior of hookers, Afro-Brazilian and "savage" women.
\end{abstract}

Key Words: Gender, Race, Sexuality, Modernity. 
Entre os anos 1910 e 1920, o literato Humberto de Campos manteve um famoso personagem, o Conselheiro X.X. Tratava-se de um respeitável diplomata aposentado que manteve por anos colunas em periódicos da imprensa carioca, chegando a fazer uma surpreendente e bem-sucedida incursão no teatro de revista em 1925, com a peça Fora do Sério, em parceria com o Barão de Oele, personagem de Oscar Lopes. O conselheiro tinha pontos de vista bem definidos sobre assuntos relativos ao comportamento, mostrando-se não raro indignado com as vestimentas utilizadas pelas jovens da época e conclamando as autoridades eclesiásticas a tomar uma iniciativa mais contundente visando proteger o recato de jovens senhoritas. ${ }^{1}$ Em outros momentos, o ferrenho católico lançava seus olhares a outros elementos que lhe desagradavam, como os jovens bem vestidos conhecidos como "almofadinhas", o enredo dos popularíssimos filmes românticos do período ou as atividades realizadas na escuridão das salas de cinema. ${ }^{2}$ Sendo assim, não é propriamente surpreendente que X.X. também se opusesse às excitantes danças que desde o fim do século anterior tomavam de assalto os salões de dança de toda a Capital Federal. ${ }^{3}$ Em uma crônica indignada o autor faz notar a "falta de decoro" e a "sem cerimônia" que observava nas "pequenas festas da burguesia" e "bailes familiares da classe média". Descreve então um incidente que teria presenciado, envolvendo sua afilhada, Alaíde:

\footnotetext{
${ }^{1}$ Ver alguns exemplos: O Exagero das Modas. O Imparcial, 11-1-20; O Clero e as Modas. O Imparcial, 21-1-20; Regeneração. O Imparcial, 31-1-20; Decotes. $O$ Imparcial, 25-2-20.

2 O Almofadinha. O Imparcial, 22-4-20; Convenções. O Imparcial, 24-5-20; Os Cravos. O Imparcial, 31-5-20; Propaganda Cinematográfica. O Imparcial, 14-620; O Perfume. O Imparcial, 18-9-20.

3 Exemplos são Dudedícia. O Imparcial, 14-8-20; Fortunato. O Imparcial, 16-820; O Pé e o Sapato. O Imparcial, 4-11-20.
} 
Massais, mulatas, meretrizes

Apresentada, no baile, a diversos rapazes do conhecimento do dono da casa, concedeu a menina um tango a um deles, que lhe pareceu, entre todos, o mais gentil e civilizado. Ao romper a música, o dono correu para ela, passou-lhe as mãos pelas espáduas $e$, apertando-lhe ao corpo, saiu a sacolejar-se pela sala, sacudindo-o desesperadamente como quem sacode, à cabeça do doente, um vidro de remédio. Ao vê-la nas garras impiedosas daquele bárbaro, o meu primeiro pensamento foi atirar-me contra ele e arrebatar-lhe a menina; olhando, porém, os outros pares, observei que todos dançavam com a mesma licença, com a mesma liberdade, com a mesma falta de escrúpulo, e, por prudência, voltei os olhos para não ver. ${ }^{4}$

Tal condenação não surpreende o leitor acostumado aos pontos de vista expressos por X.X. em sua crônica diária, e tampouco torna seu autor um fenômeno singular, já que as páginas da imprensa da época continham inúmeros textos com a mesma opinião. Nas linhas escritas pelo veterano conselheiro há, contudo, um elemento que merece ser sublinhado. Afinal, o leitor atento não poderia deixar de perceber que as linhas acima descrevem um evento da "boa sociedade" em termos muito próximos à maneira pela qual muitas vezes se buscava estigmatizar eventos vistos como pouco respeitáveis. A verdade é que X.X. parecia ver naquela reunião "burguesa" algo muito semelhante ao que veria em uma gafieira da Praça Tiradentes ou em uma animada agremiação carnavalesca mais humilde, incluindo a referência aos "bárbaros" e a explícita sexualização do estilo de dança descrito. Aqui, o piedoso conselheiro deixa entrever algo que está subjacente a uma boa parte das críticas aos estilos de vida adotados pela juventude de classe média e alta a partir do final do século XIX. Nesta visão, ao abraçar alguns dos signos da modernidade os jovens burgueses estariam aproximando-se perigosamente dos hábitos de camadas menos

4 Os Fósforos. O Imparcial, 17-7-20. 
respeitáveis da sociedade. Este ponto de vista não era particular à visão do conselheiro, sendo compartilhado por outros autores que escreviam na grande imprensa carioca naqueles anos. Em tal contexto, este artigo tem por objetivo explorar a forma pela qual as discussões sobre gênero no contexto dos anos 1920 são estruturadas por questões ligadas a outras categorias, como raça, classe e sexualidade. ${ }^{5}$

Um exemplo de teor semelhante ao do texto citado está em uma crônica em que o autor narra o que teria sido seu primeiro contato com um almofadinha e uma melindrosa, em uma estadia em Petrópolis:

Vi-os dançando um maxixe lânguido, sinuoso, cheio de licenciosidades profanas. (...) Os dois tipos generalizaramse, reproduziram-se, multiplicaram-se assustadoramente. Dominaram o mundanismo elegante das meninas e dos rapazes - ele, o almofadinha, ela a melindrosa. E o exagero das danças foi aumentando num crescente assustador.

E o que essas danças querem exprimir?

Dizem os títulos das músicas com que as acompanham: é o "samba", o "choro"; "Meu Deus, Quando?", "É Assim Que Eu Gosto!", "Não Mexa Comigo, seu Honorato!", "Lá Vem Besteira", "Cadê Ele?", "Ai Juquinha!".

\footnotetext{
${ }^{5}$ No plano teórico este objetivo já foi sugerido por autoras como BROWN, Elsa Barkley. "What Has Happened Here?": the politics of difference in women's history and feminist politics. Feminist Studies, 1992, pp.295-312 e Higginbotham, Evelyn Brooks. African-American Women's History and the Metalanguage of Race. Signs, Chicago, 1992, pp.251-274. Estudos empíricos bem sucedidos neste objetivo foram, entre outros, BEDERMAN, Gail. Manliness \& Civilization: a cultural history of gender and race in the United States, 1880-1917. Chicago-London, The University of Chicago Press, 1995, 307p.; HALL, Jacquelyn Dowd. "The Mind That Burns In Each Body": women, rape and racial violence". In: Snitow, Ann, Stansell, Christine e ThOmpson, Sharon. (orgs.) Powers of Desire: the politics of sexuality. New York, Monthly Review Press, 1983, pp.328349; Walkowitz, Judith R. City of Dreadful Delight: narratives of sexual danger in late-victorian London. Chicago, The University of Chicago Press, 1992, 353p.
} 
Massais, mulatas, meretrizes

Eis aí a dança das lindas mulheres do Rio, que desejaríamos ver tão perfeitas no moral quanto são sedutoras nas formas. ${ }^{6}$

Tal como o Conselheiro X.X., Álvaro Sodré parecia diagnosticar a formação de uma subcultura particular entre os jovens adultos das classes média $e$ alta, $e$ a ambos os autores parecia que a adoção de elementos da modernidade muitas vezes significava uma difusão entre o "mundanismo elegante" de elementos culturais vistos como pouco respeitáveis. Na verdade, os ritmos sacolejantes, as escuras salas de cinema com seus filmes palpitantes, as modas recentes no vestuário e os banhos de mar acabavam, nas primeiras décadas do século XX, por criar uma subcultura transnacional que incluía jovens de todo o mundo ocidental, incluindo aqueles de "boas famílias". ${ }^{7}$ Pode-se ver, por exemplo, que surgia entre estes indivíduos uma identidade estabelecida a ponto de realizarem verdadeiros charivaris contra pessoas de idade mais avançada que pretendessem adotar suas práticas. Um exemplo é narrado por um jornalista ao descrever um tumulto próximo ao Largo da Segunda-Feira, quando uma aglomeração ocorreu em frente a uma barbearia. Motivo: segundo um policial "uma velhota de mais de cinqüenta anos que está cortando o cabelo a la garçonne, e agora o povo quer dar vaia nela". 8

E, ao menos no Rio de Janeiro nos anos 1920, uma forma de expressar desgosto perante estas práticas era apontar aos jovens mundanos algumas semelhanças entre suas práticas $e$ o

6 Texto assinado por Álvaro Sodré em Fon-Fon, 31-1-20.

7 Sobre este contexto ver por exemplo BESSE, Susan K. Restructuring Patriarchy: the modernization of gender inequality in Brazil, 1914-1940. Chapel HillLondon, North Caroline University Press, 1996, cap.1 e BoNADIO, Maria Cláudia. Moda: costurando mulher e espaço público. Estudo sobre a sociabilidade feminina na cidade de São Paulo, 1913-1929. Dissertação de Mestrado, IFCHUnicamp, 2000, 186p.

8 YVES. La Garçonne. Fon-Fon, 28-6-24. 
que se via em regiões menos respeitáveis da cidade. Uma novidade que atraiu em particular este tipo de crítica foi a moda dos cabelos curtos, ou a la garçonne. ${ }^{9}$ Difundido por todo o mundo ocidental logo após o fim da primeira guerra mundial, esse estilo de corte de cabelo irritava particularmente a muitos não apenas por criar um elemento que atrapalhava a diferenciação entre os sexos, mas também por ser facilmente adotado por pessoas de todos os grupos sociais. Ocupando o espaço nobre de uma revista ilustrada carioca, um articulista afirmava que, "lançada, entre nós, a moda do cabelo a la garçonne todas as cabeleiras do grand monde - e as carapinhas do bas fonds rolaram à tosquia dos fígaros". ${ }^{10}$ Apontando algo semelhante a um nivelamento de raças e classes sociais através de uma forma de cortar o cabelo, este autor dava o tom do que seriam muitas críticas às novidades adotadas pela juventude de classe média $e$ alta das primeiras décadas do século, vistas aqui como elementos desagregadores de uma hierarquia social estabelecida. Outros autores seguiam caminhos semelhantes:

Avistei sábado, no Catete, uma autêntica crioula carioca, vestida de tafetás, com laçarotes de fitas na carapinha $e$ trejeitos de melindrosa trepada no salto Luís XV.

Não resisti, $e$ atirei-lhe às faces ruborizadas pelo carmim:

- Adeus, Gigolette dos morenos...

Ela endireitou o busto como para repelir-me, e exclamou, numa expressão sincera:

- Sai, despacho... Gigolette é baixo... La Garçonne do

Catete sim, meu benzinho!

\footnotetext{
9 Sobre este modismo ver ROBERTS, Mary Louise. "This Civilization No Longer Has Sexes": La Garçonne and cultural crisis in France after World War I. Gender \& History, Oxford, 1992, pp.49-69; SoHN, Anne-Marie. La Garçonne Face à L'Opinion Publique: type littéraire ou tye social des anées 20? Le Mouvement Social, Paris, 1972, pp.3-27; ZDATNY, Steven. La Mode à la Garçonne, 19001925: une histoire sociale des coupes de cheveux. Le Mouvement Social, Paris, 1996, pp.23-56.

${ }^{10}$ Portela, Bastos. Garçonismo em Perigo. Fon-Fon, 1-11-24.
} 
Massais, mulatas, meretrizes

E desapareceu, batendo com força os saltinhos na calçada.

O Catete civiliza-se... ${ }^{11}$

Ao narrar o hipotético encontro com "uma autêntica crioula carioca" este cronista indica que o termo a la garçonne, mais que um corte de cabelo, parecia aglutinar toda uma experiência da modernidade, experiência que, na visão deste autor, parecia demasiado compartilhada entre elementos de raças e classes diversas. Essa difusão de um estilo de vida parecia-lhe a comprovação de que havia algo errado com as novidades da época.

E como se difundiam estas novidades a ponto de se tornarem compartilhadas por milhões de pessoas por todo o mundo ocidental? Por certo o onipresente cinema exercia influência sobre platéias de todo o globo, mas havia também veículos locais a partir dos quais se disponibilizava um repertório comum a indivíduos de diversos grupos sociais. No caso carioca, um exemplo bastante significativo é o teatro de revista. Forma de entretenimento bastante popular desde o fim do século XIX nas grandes cidades do ocidente, o teatro de revista funcionava como uma arena local de debates, que se não tinha poder para rivalizar com a avassaladora presença do cinema, não deixava de ter sua esfera de influência. Um autor já citado comentava, por exemplo, a generalização e a febre da gíria "Comidas Meu Santo!" a partir de seu aparecimento no teatro de revista:

Já foram ver a peça Cala a Boca Etelvina?

Se não foram, vão. É deliciosa. Há nela uma criadinha de truz, mulatinha clara e dengosa que, fazendo o papel de dona de casa, não esquece o seu linguajar de esquina. $\mathrm{O}$ curioso é que o dialeto que fala é o mesmo hoje em dia usado pelas meninas do bom tom, nos salões dos dancings

${ }^{11}$ La Garçonne. Fon-Fon, 15-3-24. 
Tiago de Melo Gomes

niveladores de todas as classes e mesmo no seio do nosso famigerado congresso. ${ }^{12}$

Aqui se nota claramente a presença de uma série de elementos que o autor lança mão para criticar o que via como sendo um nivelamento social trazido pela modernidade. $\mathrm{O}$ primeiro elemento é o nivelamento pela via da classe social, já que as "meninas do bom tom" estariam aderindo ao vocabulário de suas criadas. No mesmo sentido nota-se a presença em cena do fator racial, já que a criada utilizada como exemplo é definida como "mulatinha". Como novidade em relação aos textos citados anteriormente, tem-se em primeiro lugar uma maior explicitação do desagrado em relação ao que o autor via como nivelamento entre as classes, personificado nos dancings, o que novamente traz a temática das danças como elemento a aproximar perigosamente "as meninas do bom tom" de suas criadas pobres de pele escura. Outra singularidade deste texto é que se insere discretamente a temática da sexualidade como elemento de crítica da modernidade. A forma pela qual o autor caracterizou a criada em questão torna-a uma clássica "mulata", constantemente (desde muito antes daquele período e até os dias de hoje) representada como símbolo de uma sexualidade exacerbada, típica dos africanos e seus descendentes. ${ }^{13}$ Ao relacionar esta criada às

${ }^{12}$ SodRÉ, Álvaro. Páginas da Cidade. Fon-Fon, 27-6-25.

${ }^{13}$ Ver, entre outros, CoRRÊA, Mariza. Sobre a Invenção da Mulata. Cadernos Pagu (6/7), Campinas-SP, Núcleo de Estudos de Gênero - Pagu/Unicamp, 1996, pp.35-50; QUEIRÓz JR., Teófilo. Preconceito de Cor e a Mulata na Literatura Brasileira. São Paulo, Ática, 1982, 123p.; SAnT'AnNA, Affonso Romano de. A Mulher de Cor e o Canibalismo Erótico na Sociedade Escravocrata. In: $O$ Canibalismo Amoroso. Rio de Janeiro, Brasiliense, 1984, pp.17-60. Estudos no campo da história social apontando o estigma associado às afro-brasileiras no campo da sexualidade são CAULFIELD, Sueann. Em Defesa da Honra: moralidade, modernidade e nação no Rio de Janeiro (1918-1940). Campinas, Ed. Unicamp/Cecult, 2000, 393p. e EsTEVES, Martha de Abreu. Meninas Perdidas: os populares e o cotidiano do amor no Rio de Janeiro da Belle Époque. Rio de Janeiro, Paz e Terra, 1989, 212p. 
Massais, mulatas, meretrizes

"meninas do bom tom", o autor do texto claramente endereçava sua crítica às últimas, sugerindo que adotavam um comportamento o qual fatalmente as projetaria como donas de uma maior permissibilidade sexual.

E embora tal advertência estivesse apenas subentendida no texto, não há dúvidas que os leitores tinham à mão todos os elementos para compreenderem perfeitamente o recado. Para qualquer lado que olhasse um carioca dos anos 1920 se depararia com associações bastante explícitas entre ascendência africana $e$ a idéia de sexualidade excessiva. E não restam dúvidas de que a já então recorrente figura da "mulata" exerceu papel central nesta visão racializada da sexualidade. ${ }^{14}$ A própria imprensa trazia exemplos suficientes:

Um conhecido diplomata, tão relacionado nas rodas de Petrópolis, há dias no trem fazia um cerco terrível de olhares a... uma senhora escura que the era vizinha de lugar. Ela entretanto não cedeu. Portou-se como gente branca. ${ }^{15}$

A hipersexualização de afro-brasileiros nem sempre era tão claramente explicitada, mas tornava-se bastante evidente com freqüência no vocabulário escolhido para representá-los:

Encontrei ontem, na Casa da Sereia, na Praia de Botafogo, um legítimo tipo de Vênus. Era uma Vênus preta. Alta, esbelta, feições finas, um corpo perfeito. Um vestido simples, mas com um donaire admirável.

Fiquei a olha-la demoradamente. Comigo, olhava-a também o jornaleiro, um italiano gordo de bigodões

\footnotetext{
${ }^{14}$ Ver SEIGEL, Micol e GomES, Tiago de Melo. Sabina das Laranjas: gênero, raça e nação na trajetória de um símbolo popular, 1889-1930. Revista Brasileira de História, n 43, São Paulo, 2002.

${ }^{15}$ Trepações. Fon-Fon, 4-12-20.
} 
grandes. Quando os nossos olhares se encontraram, o italiano sorriu:

- Bela madona, signore! E que catinga!

E lá se foi toda a poesia de Vênus que se exibia àquela hora naquela esquina da Voluntários da Pátria. ${ }^{16}$

A referência ao odor que a "Vênus" em questão exalaria, dotada de tal naturalismo, mostra que os afro-brasileiros eram descritos freqüentemente em tons mais fortes que os membros das classes média e alta, ou mesmo que os brancos pobres. Mas a ausência de cerimônia com que o autor descreve o inequívoco desejo sexual que a "Vênus" lhe desperta é igualmente sintomática de que a erotização de corpos afro-brasileiros era um elemento, senão compartilhado, pelo menos familiar a todos os leitores destes textos. Um segundo exemplo é uma discussão realizada por um jornalista sobre o fato de um beijo ser ou não um crime:

o beijo que se dê num quarto fechado não é crime; não é crime o beijo que se dê na mão ou na testa. Ao passo que se o ósculo na Praia do Flamengo e for, por exemplo, no catingueiro da mulata, isto é, no pescoço - o sujeito vai para a geladeira. ${ }^{17}$

À parte o contexto desta discussão, torna-se claro que uma "mulata" deveria ser percebida em termos claramente sexualizados.

Assim, ao comparar seu vocabulário com a de uma "criadinha de truz, mulatinha clara e dengosa", Álvaro Sodré desejava claramente apontar às "meninas do bom tom" o risco que corriam ao adotar práticas culturais compartilhadas por suas criadas. Um exemplo bastante explícito no mesmo sentido, e

${ }^{16}$ Vênus Negra. Fon-Fon, 22-9-23.

${ }^{17}$ PADILHA, Fortunato. As Entrevistas Momentosas. O Paiz, 23-10-25. 
Massais, mulatas, meretrizes

novamente utilizando uma criada doméstica como parâmetro, é um pequeno conto publicado na revista Careta. ${ }^{18} \mathrm{O}$ texto narra a paixão de Madame Solano por seu próprio corpo, o que terminaria por levá-la à loucura. No parágrafo final, a história se encerra em termos visivelmente sexualizados:

Madame Solano, cada vez que tinha uma dessas alucinaçóes lascivas, murmurava de dentes cerrados ao tombar hirta sobre o leito no último espasmo, em pleno delírio final de uma volúpia bárbara, como que fulminada.

Contudo, esta característica não era apontada como "natural" à protagonista da historieta. $\mathrm{Na}$ abertura do texto é mostrada apenas como uma vaidosa jovem de boa família:

Madame Solano depois de mirar-se mais uma vez com um sorriso de triunfo no grande espelho que ficava defronte do leito, voltou-se para a criada e acariciando com as mãos os seios, alisando os quadris, aprumou-se envaidecida, perguntando-lhe serenamente:

- Achas-me bela, Joana?

A criada fitou-a de alto a baixo e muito contente por poder lisonjeá-la, afastou-se para o meio da sala e pôs as mãos nas ancas, exclamando em tom solene:

- Madame é mesmo bem feitinha de corpo!

Assim, a jovem em questão é mostrada como uma entre tantas de sua idade, apenas desejosa de mostrar-se atraente. Contudo, um olhar mais atento é capaz de detectar os propósitos moralizantes do autor logo nesta abertura do conto, já que Solano é descrita em tons um tanto mais naturalistas do que seria de esperar, não deixando de ser mencionados os seus quadris $e$ seios, fato inusitado em se tratando de uma "madame" de elevado nível social. Após a fala da protagonista, sua criada é

${ }^{18}$ Careta, no 624, 5-6-20. 
descrita de forma já mais crua, havendo referência às suas "ancas", bem como sua fala contém um tom mais sexualizado. O leitor já tem motivos para desconfiar que está diante de uma crítica ao que o autor via como vaidade exacerbada, resultado da vida moderna. As preocupações de uma jovem "madame" e de sua criada (muito provavelmente afro-brasileira) em relação ao corpo como objeto de desejo são retratadas como semelhantes. Com o desenvolvimento da história, Madame Solano, como foi visto apaixona-se doentiamente pelo seu corpo, e nesta parte da história o autor a descreve com termos já abertamente explícitos em seu caráter erótico ("lascivas", "volúpia"). O objetivo do autor parece ter sido retratar sua visão de que os hábitos da vida moderna aproximavam senhoritas de boas famílias e suas criadas, incluindo hábitos sexuais, o que surge mais claramente através da curta participação da criada, que serve como um paralelo a mostrar as semelhanças entre ambas. Neste caso específico vê-se então o autor lançar mão de parâmetros de raça e sexualidade para sua discussão a respeito da relação entre gênero $e$ modernidade. Merece ainda um comentário o fato de a sexualização extrema de Madame Solano acabar por levá-la à loucura, o que não deixava de conter uma remissão às teorias degenerativas de fundo racial do século XIX, que freqüentemente relacionavam ascendência africana e sexualidade excessiva à degeneração. ${ }^{19}$

Outro exemplo esclarecedor no mesmo sentido é uma conversa que um jornalista teria presenciado no centro da cidade entre duas cozinheiras ("duas pretas que passavam", segundo o autor):

\footnotetext{
${ }^{19}$ Estas teorias foram estudadas em trabalhos como ScHWARCZ, Lilia Moritz. $O$ Espetáculo das Raças: cientistas, instituições e questão racial no Brasil (18701930). São Paulo, Cia das Letras, 1993, 287p. e VentURA, Roberto. Estilo Tropical: história cultural e polêmicas literárias no Brasil (1870-1914). São Paulo, Cia das Letras, 1991, 207p.
} 
Massais, mulatas, meretrizes

Dizia uma das tais negras à outra, referindo-se às damas do bom tom que passavam ao seu lado:

- É isto, só sabem vestir bem e andar remexendo os quartos pelas ruas? ${ }^{20}$

O diálogo criado pelo autor é de certa forma mais explícito em seus objetivos, já que mostra as cozinheiras "negras" censurando o estilo de vida das "damas do bom tom", com uma referência claramente formulada em termos sexuais, muito semelhantes ao que se descreveria uma "mulata" do teatro de revista. E o fato de esta censura partir de duas "negras" conferelhe ainda maior força, pois, como se viu, a ascendência africana era vista como um elemento a reforçar a sexualidade de quem a possuísse. O comentário citado, estando na boca de uma pessoa cuja moralidade subentendia-se ser mais relaxada, ganha assim uma enorme contundência, afirmando virtualmente que tais "damas" exibiriam uma performance corporal tão erotizada quanto mulheres vistas como menos respeitáveis. Novamente raça e sexualidade, bem como classe, são utilizadas para expressar descontentamento sobre as novidades do mundo das relações de gênero desde o início do século.

A já muito conhecida figura da "mulata" não era, contudo, a única referência em textos como o acima citado. A visível sexualização que muitos viam em jovens como Madame Solano estava ancorada não apenas em termos raciais, mas pode-se notar ainda a presença de uma outra figura atuando como parâmetro nesta associação entre modernidade e sexualidade: a da prostituta. ${ }^{21}$ A referência das "pretas" citadas acima a respeito das melindrosas que "remexiam os quartos" pelas ruas remete diretamente a textos como uma crônica do literato Antônio

${ }^{20}$ Bolchevismo de Cozinha. Fon-Fon, 4-7-25. p. 3.

${ }^{21}$ Sobre a prostituição no Rio de Janeiro, ver SOARES, Luís Carlos, Rameiras, Ilhoas, Polacas: a prostituição no Rio de Janeiro do século XIX. São Paulo, Ática, 1992, 118p.; CAULFIELD, Sueann. O Nascimento do Mangue: nação e controle da prostituição no Rio de Janeiro, 1850-1942. Tempo, nº 9, 2000. 
Torres. ${ }^{22}$ Discutindo a presença do cinema na Capital Federal, Torres acha que "o cinema, em si nem é bom nem é mau". Porém, crê que "no Rio de Janeiro, o cinema é altamente prejudicial. Só de raro aparece alguma fita capaz de instruir e de edificar o público". As fitas francesas seriam sempre sobre o adultério, as italianas sobre "chamas da paixão", enquanto as norte-americanas seriam sobre ambos os temas e ainda mais:

a brutalidade selvática dos vaqueiros, as correrias doidas por montes de matagais, o egoísmo metálico dos banqueiros, todo um conjunto complexo de qualidades de onde se extrai, como se isola na retorta um alcalóide, falta de elegância mental, ausência de sentimentos cavalheirescos e muita sensaboria ou mazorra.

Além disto, tais filmes seriam veículos de propaganda e completamente realistas e amorais, refletindo características norteamericanas. Com isto, seu reflexo no Brasil seria pernicioso por levar à imitação dos trajes por aqui:

Quem quiser aquilatar a influência do cinema no Rio bastalhe deter-se meia hora numa avenida $e$ ver passar as moças; com poucas exceções, o vestuário e o andar são evidentemente copiados das atrizes e meretrizes dos cinemas. Antigamente se distinguiam damas de família $e$ damas de alegre vida, quando não pelo vestuário modesto nas primeiras, espaventoso nas segundas - ao menos por certo saracoteado de ancas muito característico nas últimas e que altamente escandalizavam as senhoras honestas. Já agora é difícil distingui-las, porque o vestuário de todas é semelhante, sendo também igual em todas a gelatinosa trepidação das garupas.

Aqui Antônio Torres explicita de modo inquestionável sua visão de que as jovens melindrosas que desfilavam pelo mundo

${ }^{22}$ Se o Cinema é Útil. Gazeta de Notícias, 1-5-20. 
Massais, mulatas, meretrizes

elegante da Capital se assemelhavam cada vez mais às prostitutas, tanto no que tange ao vestuário como no campo da performance corporal. Torres se permite mesmo aludir à postura destas senhoritas através da expressão "gelatinosa trepidação das garupas", muito próxima do comentário das "pretas" citadas anteriormente a respeito das jovens "remexendo os quadris", mostrando que o jornalista colocou na boca das cozinheiras uma fala que se remetia tanto à associação entre raça e disponibilidade sexual (a figura da "mulata") como à total acessibilidade sexual (a figura da prostituta). Estas visões sobre o mundo das primeiras décadas do século, e a utilização destes elementos como contrapontos à modernidade atingiam um ponto bastante agudo em um outro artigo:

Essas meninas de agora... Andam pelas ruas e cinemas sozinhas, marcam encontro com os namorados, facilitamlhes tudo, pintam faces, orelhas, unhas, lábios, raspam as sobrancelhas, enegrecem as pestanas, usam saias acima dos joelhos, exibem as pernas depiladas, deixam adivinhar os seios pequeninos e túrgidos sob as fazendas leves, fazendoos tremelicar, rebolam os quadris, falam em suco, zinho, tirar fiapo e não sei o que mais. Assim, perderam para sempre o encanto daquela idade entre menina e moça, que só deve despertar encanto e respeito. ${ }^{23}$

O jornalista citado reúne em poucas linhas muitos dos elementos críticos ao comportamento dos jovens de classe média $e$ alta das primeiras décadas do século XX. Irritava particularmente ao autor as relações de gênero nas quais se inseriam as "meninas de agora", que lhe pareciam insinuantes, descompromissadas $e$ mesmo permissíveis sexualmente. Novamente é possível notar que para coroar esta visão refratária às novidades utiliza-se referenciais bastante conhecidos de acessibilidade sexual, como a referência ao fato de estas jovens "rebolarem os quadris" e utilizarem

${ }^{23}$ Garatujas. Fon-Fon, 4-7-25. p.42. 
expressões vistas como inadequadas. A descrição que o jornalista faz de tais "meninas" por certo é calcada em figuras bastante simbólicas desta erotização, como a "mulata" (note-se as gírias "populares" a que o autor se refere) e as prostitutas (das quais o autor se aproxima através das referências a uma vaidade vista como excessiva, que se manifesta na ampla utilização de maquiagem e vestimentas finas). Novamente raça, sexualidade $e$ classe surgem como elementos estruturantes de um discurso refratário às novidades nas relações de gênero naqueles anos.

Como última passagem a exemplificar esta relação entre raça, sexualidade e gênero em um ponto de vista contrário às novidades das ruas, pode-se citar um jornalista que diz observar o "mundanismo carioca" de seu "ponto predileto na Avenida Rio Branco". Escreve então, a respeito de uma transeunte:

Mas aquela mocinha... Já passou... É estampa só! Modelo clássico de certas virgens contemporâneas, olha os homens com descaso, requebra os quadris, numa lúbrica provocação e sente-se com orgulho mulher para toda uma raça ao imaginar os desejos que provoca com a seminudez do corpo e o requebro musical das ancas.

A natureza deu-lhe a estampa da mocidade, mas a civilização, roubando-lhe a alma terna $e$ ingênua, essa cuja vida efêmera não devia passar das ilusões platônicas do amor, precipitou-lhe o despertar do instinto e fá-la pensar antecipadamente na caça ao homem, matando-lhe assim todos os sonhos castos da puberdade.

O espetáculo que elas em conjunto apresentam no salão é desolador, é triste, é profundamente imoral. ${ }^{24}$

Aqui as jovens melindrosas que circulavam amplamente pelo mundanismo carioca são retratadas pelo cronista virtualmente como prostitutas que se requebram seminuas

${ }^{24}$ Haristal, Mário de. Da Rua do Ouvidor ao Ponto Chic. Careta, n ${ }^{\circ} 683$, 23-07-21. 
Massais, mulatas, meretrizes

buscando atrair o desejo erótico masculino. Ao menos o primeiro parágrafo também recorre a imagens comumente associadas às "mulatas", vide o fato de provocar desejos através do "requebro musical das ancas". Mas o segundo parágrafo parece retratar uma prostituta, como por exemplo ao utilizar a imagem da desgraça causada pela vitória do instinto sobre o amor platônico. Aqui, hábitos que ganhavam espaço a cada dia (cabelos curtos, vestuário moderno, maior espaço para flertes, como as salas de cinema, etc.) eram reprovados pelo jornalista acima, que parecia tentar chamar as "mocinhas" ao juízo, apontando como estas estariam, embora talvez inocentemente, emitindo sinais de acessibilidade sexual a cada momento de sua vida cotidiana.

Se diversos dos exemplos citados anteriormente lançam mão das figuras da "mulata" e da prostituta como modelos negativos que as jovens de elite estariam seguindo, há diversos casos em que a questão racial surge claramente como a questão essencial a servir como ponto de partida para a ridicularização das novidades no comportamento nas primeiras décadas do século $\mathrm{XX}$. Exemplo típico está em uma charge que mostrava um casal de dançarinos dançando freneticamente:

- Quero ver se apronto o charleston.

- Só serve mesmo pra gente se divertir.

- Está enganada: serve para a capoeiragem dos salões. ${ }^{25}$

Aqui uma das danças mais recentemente aportadas no Brasil, executada por todas as jazz-bands que se prezassem, incluindo aquelas que atuavam nos círculos mais elitizados, aparecia como um elemento de nivelamento social, aproximando dançarinos bem posicionados socialmente dos temidos capoeiras. A crítica de fundo racial das novidades observadas no mundanismo carioca naqueles anos tornava-se mais $e$ mais perceptível à medida que elementos culturais associados aos

${ }^{25}$ Careta, no 975, 26-02-27. 
descendentes de africanos ampliavam, pela via do entretenimento de massas, sua penetração em todos os ambientes. A visão de que a cada dia se consumiam mais produtos culturais "negros" parecia ser amplamente compartilhada naquele período, o que se pode observar facilmente na própria imprensa, mesmo que sem propósitos de crítica. Um exemplo é uma crônica de 1920 que contava a história do samba carioca: "vindo de terras africanas, (...) localizou-se primitivamente nos nossos sertões, propagou-se no eito e por lá floresceu entre a preta raça". Após a Abolição e a República teriam se harmonizado as relações raciais, "e o samba docemente passou as trincheiras negras, repimpando-se no meio da raça alva". Como resultado:

hoje o samba é a coisa mais peregrina que as moças "da alta" gostosamente praticam no salão carnavalesco; e com quanta fantasia, com quanta faceirice elas sapateiam e se requebram. ${ }^{26}$

O autor desta tentativa de historiar o surgimento e difusão do samba não parecia particularmente contrário a esta ampla aceitação do samba, nem mesmo ao fato de "moças da alta" se requebrarem ao seu ritmo. Mas é previsível que esta visão sobre as origens de diversos produtos culturais, bastante difundida até os dias de hoje, desse origem a expressões de desgosto pelos caminhos tomados pela "raça alva".

Uma forma assumida por estas críticas à difusão de produtos culturais consensualmente aceitos como "negros" era a contraposição entre as idéias de "civilização" e "barbárie". O sucesso desta produção cultural por todo o mundo ocidental ajudava a reforçar a idéia de uma diáspora africana, cujos resultados seriam, entre outros, o jazz, o charleston e o samba. Um exemplo claro desta percepção pode ser visto nas páginas de um periódico carioca, em uma matéria de duas páginas intitulada

${ }^{26}$ Nos Teatros. Correio da Manhã, 24-1-20. 
Massais, mulatas, meretrizes

"Orquestras Exóticas... Músicos Excêntricos - A Origem Provável do Jazz-Band". ${ }^{27}$ A matéria era ilustrada por fotografias de cinco conjuntos musicais: quatro aparentemente eram africanos (dois trajados como muçulmanos e dois que poderiam ser lidos como "selvagens") e um era identificado como chinês. A uní-los, vestimentas e instrumentos desconhecidos. Argumenta o autor:

Além do exotismo das caras, os instrumentos são tudo quanto há de mais excêntrico, bizarro, extravagante $e$ original.

Contemplando essas gravuras quem não pensa logo que as jazz-bands tenham sido inspiradas em todos esses grupos esquisitos, de músicos primitivos, das raças mais... atrasadas...

Ele não é mesmo novo - milhares de anos atrás os bosques ecoavam suas loucas dissonâncias.

O texto citado acima claramente fortalece a idéia de uma diáspora africana, da qual as jazz-bands seriam um resultado. E é fácil imaginar que tal maneira de perceber as jazz-bands pavimentava o caminho para o surgimento de interpretações que vissem no avassalador sucesso daqueles conjuntos um sintoma de decadência da sociedade, que estaria nesta visão pronta para ingressar na barbárie. Para não deixar dúvidas, o mesmo periódico um mês depois publicou outra matéria, denominada "Uma Origem Provável dos Nossos Cordões e Ranchos Carnavalescos". ${ }^{28}$ O texto é ilustrado por cinco fotografias apresentadas como sendo "de festas africanas" $e$ conclui afirmando a existência de uma relação ancestral entre tais grupos carnavalescos e o continente africano, dando grande ênfase às danças exibidas nas imagens. Através da difusão da idéia de uma ancestralidade comum que tornava comparáveis o sucesso de produtos culturais associados aos africanos e seus descendentes

${ }^{27}$ Revista Musical, $\mathrm{n}^{\circ} 12,1-2-24$.

${ }^{28}$ ID., IB. 
em todo o ocidente, criavam-se as condições para uma estreita associação entre raça e modernidade.

Esta conexão, associada ao repertório de imagens que relacionam a ascendência africana a uma sexualidade hiperdesenvolvida, se tornaria bastante poderoso em discursos contrários às novidades que surgiam no campo do comportamento naqueles anos. Um dos jornalistas a lançar mão deste repertório observava que

as negras moças ou velhas da tribo dos Massais da África Central enfeitam-se tanto com bugigangas, brincos, pulseiras e pendéntifs como as nossas elegantes que passam pela Avenida Central. ${ }^{29}$

Aqui se nota que o autor se mostrava contrário ao que via como vaidade excessiva das jovens de classe média e alta que desfilavam pelo mundo elegante da Capital Federal. Vê-se ainda que para conferir maior contundência a seus propósitos, o jornalista recorreu a um paralelo entre as jovens que criticava $e$ um grupo de mulheres facilmente reconhecíveis por seus leitores como "bárbaras", visando lançar as "nossas elegantes" em completo ridículo. É necessário ainda observar que esta crítica às mulheres modernas não deixava de ridicularizar da mesma forma as "bárbaras" que lhes servem como paralelo. Se já foi suficientemente demonstrado que nos anos 1920 não faltavam grupos buscando a modernidade no "primitivo" 30 , a passagem acima sugere que o oposto também se dava: freqüentemente as

${ }^{29}$ O Eterno Feminino. Careta, no 858, 29-11-24 (grifo no original).

${ }^{30}$ Entre outros ver ToRgOvNICK, Mariana. Gone Primitive: savage intelects, modern lives. Chicago/London, The University of Chicago Press, 1990, 328p.; ClifFord, James. Histories of the Tribal and the Modern. In: The Predicament of Culture: twentieth-century ethnography, literature and art. Cambridge, Harvard University Press, 1988, pp.189-214. No Brasil ver PEREGRINO. Um Sorriso para Todas. Careta, n $1020,7-1-28$, p.34. 
Massais, mulatas, meretrizes

críticas às novidades se faziam em conjunto com a ridicularização do que se percebia como "barbárie".

No caso acima, as novidades da modernidade são postas em paralelo com noções racializadas de "barbárie", sem que a sexualidade das Massais em questão tenha sido colocada em destaque, visando conferir uma contundência ainda maior ao escrito publicado em Careta. Em outros casos a questão da sexualidade apareceria mais explicitamente associado à raça $e$ barbárie em críticas às novidades. Um exemplo é uma fotografia publicada em um semanário com a legenda "Moças Diolas", mostrando duas mulheres vestidas apenas com panos na altura da cintura e colares no pescoço, com seios à mostra. Ao lado, via-se escrito:

duas melindrosas africanas. Os decotes um pouco mais profundos do que os que vemos no Municipal, as saias mais curtas do que as que passam pela Avenida, não impedem que as jovens senegalescas estejam perfeitamente obedientes ao momento elegante. Pulseiras e colares são do último chic. É o que se vê nas vitrinas da rue de la Paix e da rua do Ouvidor. Será que no Senegal se lê o Chiffon? Ou será da África que tiramos as nossas modas? ${ }^{31}$

Este texto revela um autor explicitamente engajado na crítica às novidades no comportamento adotadas por muitas jovens de classe média $e$ alta de todo o ocidente nas primeiras décadas do século XX. E o caminho escolhido para atingir seus objetivos é comparar as melindrosas, símbolo maior destes novos parâmetros, a algumas africanas vestidas sumariamente, apenas para concluir que há poucas diferenças entre os dois grupos. $\mathrm{O}$ autor vê ao seu redor uma modernidade "enegrecida", que parece igualar as jovens de boas famílias da Capital Federal a símbolos evidentes do que o autor via como "barbárie". E as semelhanças entre "melindrosas" e "moças diolas" são colocadas em termos do

${ }^{31}$ Bilhete. Fon-Fon, 5-3-21. 
quanto os dois grupos de mulheres estariam dispostas a exibir partes do corpo em público, tornando este paralelo fundado também na imagem de acessibilidade sexual ostentada, na visão do cronista, pelas melindrosas. Assim, o autor constrói um quadro no qual todo o ocidente parece estar adotando padrões de comportamento semelhantes aos de selvagens africanos que não têm pudor em exibir o corpo em público, imagem que mostra com precisão o importante papel desempenhado por imagens de raça, sexualidade e civilização na crítica à modernidade.

A importância da visão amplamente compartilhada a respeito da sexualidade dita exacerbada de africanos e seus descendentes pode ser notada a partir da clara predominância, nestes paralelos entre "bárbaros" e "modernos", de indivíduos de alguma forma ligados ao continente africano. Se se tratasse meramente de uma oposição entre conceitos de civilização $e$ barbárie, sendo estes últimos representados pelo hábito de vestirse sumariamente pelos padrões da Capital dos anos 1920, outros paralelos poderiam ser facilmente traçados. $\mathrm{O}$ mais óbvio, certamente, seria com grupos indígenas brasileiros que, a exemplo dos habitantes de territórios coloniais africanos, tornavam-se progressivamente mais acessíveis a um público amplo em função de expedições oficiais, devidamente documentadas em filmes $e$ fotografias. Certamente não seria difícil a estes mesmos cronistas notarem que não faltavam indígenas em trajes que lhes pareceriam pouco adequados, e um escritor chegou a registrar tal paralelo, comparando o que viu em um filme produzido em uma expedição de Rondon e o que vê nas ruas:

Deixando a sala daquele cinema e caminhando pela avenida Rio Branco, assim como quem bruscamente se transportasse dos confins de Mato Grosso ao centro mais freqüentado da Capital do Brasil, pode-se averiguar os inúmeros pontos de contato existentes entre os costumes dos selvagens e certas maneiras dos nossos almofadinhas $e$ melindrosas; ao ponto de a gente ficar pensando se muitas das coisas que se vêem por aí, como importadas de Paris e 
Massais, mulatas, meretrizes

Londres, não seriam provenientes dos cafundós do próprio Brasil, tão desprezado pelos catitas. Lá como cá, o vestuário constitui mais um adorno, expressão de vaidade, do que qualquer longínqua determinação do pudor. ${ }^{32}$

Aqui o cronista reproduz boa parte do repertório utilizado por seus colegas que compararam melindrosas e africanas: para o sisudo jornalista, tanto entre a juventude do "centro mais freqüentado da Capital do Brasil" como "nos confins de Mato Grosso", a vaidade estava em primeiro plano em relação ao pudor. Há ainda um exemplo em que se lança mão de outra região do planeta tida como "selvagem" para defender a mesma idéia:

Passava no écran uma fita de viagens. Apareciam fisionomias de selvagens da Oceania, pintados de cores variadas, com cabeleiras encaracoladas, arrumadas no alto da cabeça, nas quais se viam ornatos bizarros e plumas longas. Das suas orelhas pendiam largos anéis de metal.

Ao meu lado, no escuro, uma voz de senhora murmurou:

- É horrivel! Que bárbaros!

Quando se fez luz na sala, olhei a dona dessas exclamações. Estava toda empoada, toda pintada: de rosa nas faces, de rubro nos lábios, de negro nas sobrancelhas e de azul nos olhos. Sobre a cabeça, trazia um verdadeiro trepa-moleque de plumas, laçarotes e enfeites. Das orelhas pendiam enormes berrequedengues. $\mathrm{E}$ eu murmurei:

- Que linda! Que civilizada! ${ }^{33}$

Contudo, os exemplos acima parecem ter sido fenômenos isolados, sobretudo se comparado à profusão de textos que utilizaram preferencialmente exemplos extraídos do continente

${ }^{32}$ Veloso, Antônio Leão. Almofadinhas e Nhambiquaras. Correio da Manhã, 25-10-20.

${ }^{33}$ Era no Cinema. Fon-Fon, 20-9-24. 
africano. As razões desta preferência servem como encaminhamento para as conclusões deste artigo. Ao traçarem paralelos entre almofadinhas ou melindrosas $e$ tipos aparentemente pertencentes a outros universos, os jornalistas citados não nos dizem muito sobre meretrizes, "mulatas", diolas, massais ou nhambiquaras. Por outro lado, mostram que a relação, já bastante enfatizada por diversos autores, entre gênero $e$ modernidade nas primeiras décadas do século XX ainda pode ser explorada em alguns caminhos. Os textos citados neste artigo sugerem que as preocupações de contemporâneos com a mudança nas relações de gênero naqueles anos tinham um forte componente associado à própria sexualidade que a eles parecia ser exibida de modo muito mais explícito nas ruas. Traçando um paralelo entre as jovens do mundo elegante da Capital $e$ um repertório de imagens fortemente sexualizadas, estes contemporâneos não escondiam uma forte ansiedade daquele período. Ao adotar padrões de comportamento que poderiam ser identificados àquele repertório, estas senhoritas burguesas de classe média e alta pareciam, na visão destes observadores, ostentar em pleno espaço público uma sexualidade que até então se julgava inexistente.

Note-se que não se tratava apenas de contrapor, pedagogicamente, prostitutas a mulheres saudáveis e higiênicas. ${ }^{34}$ Nos textos citados nota-se um verdadeiro sentimento de vertigem em função de novos comportamentos que, para muitos dos perplexos contemporâneos, soava como uma verdadeira sexualização do espaço mundano da cidade. E, mais

${ }^{34}$ Ver RAGO, Luzia Margareth. Imagens da Prostituição na Belle Epoque Paulistana. Cadernos Pagu (1), Campinas, Núcleo de Estudos de Gênero Pagu/Unicamp, 1993, pp.31-44. A mesma autora explorou com maior vagar seus pontos de vista em seu Prazeres da Noite: prostituição e códigos de sexualidade feminina em São Paulo, 1890-1930, Rio de Janeiro, Paz e Terra, 1991, 322p. Naturalmente não se pode negar esta dimensão pedagógica nestes discursos, mas é necessário apontar outros elementos além do desejo de controle sobre a sexualidade feminina. 
Massais, mulatas, meretrizes

surpreendente, esta sexualização seria vista de modo mais ostensivo na atitude pública de jovens mulheres de classe média $e$ alta, de modo que os discursos analisados operam em um contexto de sexualização, mas também de feminilização dos espaços de classe média e alta. ${ }^{35}$ Esta sensação de vertigem pode ser claramente medida neste imbricamento de discursos sobre raça, classe, gênero e sexualidade, que busca funcionar como estratégia de policiamento do comportamento de mulheres de classe média e alta, mas não deixa de estabelecer também os limites do aceitável para as mulheres pobres e/ou afro-brasileiras.

Um resumo de todos estes elementos pode ser encontrado em uma charge denominada "Preto no Branco", que mostra um casal caminhando na rua. $\mathrm{O}$ homem possui a pele escura e vestese de modo tradicional. Ela, vestida à moda moderna. Dois observadores comentam: "São casados! Ela casou-se porque ele era o preto que tinha alma branca, e ele por sua vez casou-se porque ela tinha a alma preta". ${ }^{36}$ Portanto, a passagem não esconde sua visão de que ter "alma branca" é comportar-se dentro dos padrões há muito estabelecidos, enquanto a "alma preta" é relacionada às novidades. A associação aqui é clara: enquanto à raça branca corresponderia a tradição do vestuário, os "pretos" seriam o equivalente racial da modernidade, que aparece aqui definitivamente "enegrecida". O recado parece claro e dirigido para a juventude inserida na "vida moderna", representada por seus tipos quintessenciais, o almofadinha $e$ a melindrosa: ser moderno é comportar-se como um afro-brasileiro típico, com todas as implicações daí decorrentes. Buscando coibir os comportamentos de "jovens senhoritas" bem como dar lições de civilidade aos afro-brasileiros, a charge mostra um aspecto importante da atmosfera mental do período: o pânico perante o

\footnotetext{
${ }^{35} \mathrm{Um}$ trabalho canônico sobre a tomada das ruas por jovens do sexo feminino, ainda que enfocando grupos de menor poder aquisitivo é PEISS, Kathy. Cheap Amusements: working women and leisure in turn-of-the-century New York. Philadelphia, Temple University Press, 1986, 244p.

${ }^{36}$ Careta, no $1064,10-11-28$.
} 
Tiago de Melo Gomes

que parecia a muitos observadores a sexualização, a feminilização $e$ a dissolução de fronteiras de raça e classe no espaço público das grandes cidades. 